Discussion Paper No. 08-094

\title{
Firm Closure, Financial Losses
} and the Consequences for an Entrepreneurial Restart

Georg Metzger

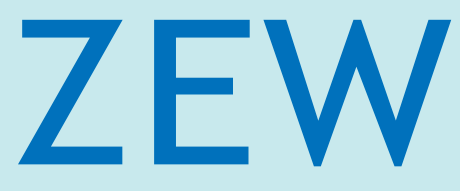

Zentrum für Europäische Wirtschaftsforschung $\mathrm{GmbH}$

Centre for European Economic Research 


\title{
Discussion Paper No. 08-094 \\ Firm Closure, Financial Losses and the Consequences for an Entrepreneurial Restart
}

\author{
Georg Metzger
}

Download this ZEW Discussion Paper from our ftp server:

ftp://ftp.zew.de/pub/zew-docs/dp/dp08094.pdf

Die Discussion Papers dienen einer möglichst schnellen Verbreitung von neueren Forschungsarbeiten des ZEW. Die Beiträge liegen in alleiniger Verantwortung der Autoren und stellen nicht notwendigerweise die Meinung des ZEW dar.

Discussion Papers are intended to make results of ZEW research promptly available to other economists in order to encourage discussion and suggestions for revisions. The authors are solely responsible for the contents which do not necessarily represent the opinion of the ZEW. 


\section{Non-technical summary}

Individuals who want to become entrepreneurs need to spend time on an important aspect: risk. They risk not only their financial well-being, their career, their family relations, but also their physical well-being. Indeed, asking nascent entrepreneurs about anxieties preventing them from becoming entrepreneurs at the end, they prominently refer to financial risks. However, is their fear justified? How likely is it that entrepreneurs suffer private losses from business closure? And what does it mean for their entrepreneurial career if private losses occur? May it even be more likely that losses at other stakeholders are more important for an entrepreneurs' further entrepreneurial career?

Financial losses arising from business closure can befall various stakeholders: shareholders, banks and public institutions, or suppliers and other stakeholders. It is reasonable to expect that financial losses impact the likelihood of a restart as a function of the stakeholders who have been forced to bear losses. Because most start-ups rely on entrepreneurs' own capital there is a high probability that entrepreneurs themselves are financially affected by loss-making business closures. This would, as a consequence, reduce their personal wealth, the fundament of future actions. However, it is of twofold importance if banks suffer losses. First, losses at banks are likely to be strong correlated with personal losses of the entrepreneurs reducing entrepreneurs' personal wealth. Second, losses at banks are "public" debts impeding the chance of credit from other banks. Both are bad for restart feasibility.

Multivariate analyses reveal that the occurrence of private losses of the entrepreneurs does not affect the restart likelihood. Losses are merely important if they arise at banks or public institutions. Then, restart is less likely. This effect may be the result of the role that banks play with respect to start-up financing, where they are often the first address to turn on. Furthermore, the type of closure matters. Restart probability is higher if the closure was result of management disagreements. Surprisingly, restart probability is independent from closure types that can be considered a business failure. This means, that if closures took place because the business development does not meet the entrepreneurs' target thresholds of performance or because of liquidity problems or excessive debts arose, restart likelihood is not affected significantly. This was not expected since other studies show that restart is less likely in the case of business failure. However, it might be that there the closure type measures capture effects that actually come from incurred losses for which it was not controlled.

The major finding of this analysis is that financial losses due to business closure are important for the occurrence of an entrepreneurial restart - if the losses incur at banks. This has an important implication for entrepreneurs. Entrepreneurs who want to continue their entrepreneurial career after a business closure should avoid losses at banks or public institutions. 


\section{Das Wichtigste in Kürze}

Mit einer unternehmerischen Selbstständigkeit gehen viele unterschiedliche Risiken einher: finanzielle, berufliche, familiäre, oder gesundheitliche Risiken. Trotz der Fülle an Risiken steht bei den meisten angehenden Unternehmern jedoch die Sorge vor dem finanziellen Risiko im Vordergrund. Die Frage ist, ob diese Sorge gerechtfertigt ist. Wie wahrscheinlich ist es, dass eine Unternehmensschließung finanzielle Verluste für den Unternehmer mit sich bringt? Was würden solche privaten finanziellen Verluste für ihre weitere unternehmerische Karriere bedeuten? Welche Auswirkungen haben Verluste, die die Unternehmer nicht selbst tragen müssen, auf deren weitere unternehmerische Karriere?

Tatsächlich kann erwartet werden, dass die Auswirkung finanzieller Verluste, die durch eine Unternehmensschließung entstehen, auf die weitere unternehmerische Karriere der Selbstständigen davon abhängt, wer die Verluste zu tragen hat. Weil im Allgemeinen keine Unternehmensgründung ohne Eigenmittel der Gründer auskommt, ist es wahrscheinlich, dass die Unternehmer bei einer verlustbehafteten Unternehmensschließung auch selbst finanziell betroffen sind. Entsprechend eingeschränkt werden würde der finanzielle Spielraum der Unternehmer. Eine doppelte Bedeutung hat es wenn Banken durch eine Unternehmensschließung finanzielle Verluste davontragen. Zum einen gehen finanzielle Verluste bei Banken auch sehr wahrscheinlich mit privaten finanziellen Verlusten bei den Unternehmern einher. Zum anderen würde der Zugang zu neuen Krediten eingeschränkt, was die Finanzierung einer erneuten Unternehmensgründung erschweren würde.

Diese Untersuchung zeigt, dass finanzielle Verluste, die im Zuge einer Unternehmensschließung anfallen, sich nur dann auf die Neustartwahrscheinlichkeit auswirken, wenn Banken oder öffentliche Institutionen sie zu tragen haben. Gegenüber Schließungen, bei denen Verluste von anderen zu tragen sind, ist dann ein Neustart unwahrscheinlicher. Auch der Grund, weshalb ein Unternehmen geschlossen wurde, spielt eine wichtige Rolle. Gegenüber anderen Schließungsgründen ist die Neustartwahrscheinlichkeit höher, wenn Meinungsverschiedenheiten in der Geschäftsführung ein Grund für die Unternehmensschließung waren. Die Indikatoren, die auf ein unternehmerisches Scheitern als Ursache für die Unternehmensschließung hindeuten, zeigen dagegen keine signifikanten Effekte. Dies ist unerwartet, da in früheren Untersuchungen solche Indikatoren signifikante Effekte zeigen. Dies könnte jedoch darauf zurückzuführen sein, dass in den früheren Studien keine Angaben über angefallene finanzielle Verluste zur Verfügung standen und unberücksichtigt bleiben mussten.

Finanzielle Verluste, die durch eine Unternehmensschließung entstehen, haben Einfluss auf die Wahrscheinlichkeit eines unternehmerischen Neustarts - wenn Banken die Verluste zu tragen haben. Entsprechend den Ergebnissen ist es für einen Unternehmer bedeutsam, im Zuge der Unternehmensschließung finanzielle Verluste bei Banken zu vermeiden oder zumindest gering zu halten, sollte eine Fortsetzung der unternehmerischen Karriere nach der Unternehmensschließung beabsichtigt sein. 


\title{
Firm closure, financial losses and the consequences for an entrepreneurial restart
}

\author{
Georg Metzger \\ ZEW Centre for European Economic Research, Mannheim \\ P.O.Box 103443 \\ 68034 Mannheim, Germany \\ Phone: +49621 1235-185, e-mail: metzger@zew.de \\ www.zew.de
}

\begin{abstract}
Many entrepreneurs who close a business are actually willing to venture anew. However, to realize a restart is not only a matter of willingness on the part of the entrepreneur but also of its feasibility. Regarding the feasibility of a restart, the aspect of capital acquisition might be particularly precarious for renascent entrepreneurs since business closures are likely to come up with financial losses. Financial losses arising from business closure can befall various stakeholders: shareholders, banks and public institutions, or suppliers and other stakeholders. The major finding of this analysis is that financial losses due to business closure strongly influence the likelihood of entrepreneurial restart - yet only when losses are incurred by banks. Losses which are incurred privately by the entrepreneurs or by other stakeholders do not influence the restart likelihood. Entrepreneurs who would seek to continue their entrepreneurial career after a business closure would be well advised to avoid causing losses at banks.
\end{abstract}

\section{Keywords}

Firm closure; financial loss; restart.

\section{JEL-Classifications}

G33; L26; M13. 


\section{I ntroduction}

Entrepreneurs who have abandoned a business must weigh a number of personal, social and economic factors when deciding to start a new business (Dyer, 1994). Yet the act of restarting presupposes both willingness on the part of the entrepreneur and its objective feasibility. Rational entrepreneurs' willingness to restart is primarily influenced by the expectancy of future self-employment profits compared to other income alternatives. While the former lies within the purview of the entrepreneur, the latter may be determined to large extent by external individuals and institutions - particularly in the case of a previous business failure and/or financial losses. This is also recognized by Stam et al. (2006) who note: "[...] how the prior business of the ex-entrepreneur was terminated [...] impact not just the post-entrepreneurial career in general, but also renascent entrepreneurship in particular" (Stam et al., 2006, p. 8).

To date no study analyzing the effects of different types of abandoning a business on the restart likelihood (e.g. Metzger, 2008 or Stam et al., 2006) has attempted to differ between the willingness of entrepreneurs to restart and its objective feasibility. This article aims to address this gap in scholarship. By including measures that account for stakeholder groups who bear financial losses arising from business closure, feasibility can be approximated and its effects on the likelihood of an entrepreneurial restart can be analyzed. To do so, unique data of foundations in Germany is used containing information about financial losses due to business closures.

\section{Entrepreneurial restarts}

Many entrepreneurs who close a business are discouraged and choose the exit option, i.e. turn their backs on entrepreneurship (Ronstadt, 1986). Others are unflagging. They engage in several firms swallowing also business failures before they find "their" business (Ronstadt, 1982). Renascent entrepreneurs i.e. entrepreneurs who closed a business and prepare their restart can be characterized by several factors. One of the first analyses which considered such latent restarters is that of Wagner (2003). He investigated in which respects entrepreneurs who had 'closed or given up' a firm in the past and who toying with the idea to venture anew differ from those who leave the entrepreneurial career path. Relying on survey data he found that especially entrepreneurs who are youngish and higher educated aspire to take the second chance. The latent restarters are, in addition, comparatively less risk averse and have rather more contact with other start-up entrepreneurs. Stam et al. (2006) also used survey data to characterize renascent entrepreneurs and came to the conclusion that the human capital of the ex-entrepreneurs is indeed very relevant. Highly educated entrepreneurs and those with multipleentrepreneurial experiences are more prone to restart than others, as are entrepreneurs who abandon a business by the way of selling it. The human capital effect is confirmed by Schutjens and Stam (2006). Based on a small sample analysis, they show that experience is crucial and positively affects restart probability. 


\section{Derivation of hypotheses}

The reasons why entrepreneurs close their business are many and diverse. Closures may be the result of economic pressures, such as insolvency or bankruptcy, or strategic reasons, such as an effort to avoid bankruptcy or absolve guarantee claims. In most cases closures are not economically inevitable. Entrepreneurs often close businesses 'voluntarily' in order to return to the workforce, enter retirement, make a clean break and open a different business, or due to health reasons, etc. Yet regardless of the ultimate cause of closure, its occurrence can be emotionally burdening for the entrepreneur (Sheperd, 2003). Once 'discouraged' (Stokes and Blackburn, 2001), entrepreneurs may conclude they are not up to the task of self-employment, as they 'learn' about their own inabilities (Jovanovic, 1982). This depresses the profit expectations of further self-employment and may prevent restart if profit expectations are negative, i.e., below that expected from an alternative mode of employment. This scenario is particularly likely in the case of business failure, when entrepreneurs are more inclined to become pessimistic about future attempts (McGrath, 1999). While discouraged entrepreneurs may have a lowered willingness to start afresh, the feasibility of establishing a new business may also be restricted.

Metzger (2008) analyzed the occurrence of real restarts considering particularly the effect of how a previous business was abandoned. Failed entrepreneurs i.e. entrepreneurs who closed a cash-strapped firm voluntarily or went bankrupt are less likely to restart than other experienced entrepreneurs who closed a firm. However, if entrepreneurs chose unlimited liability legal forms, capital constraints can lower the restart probability additionally. Business failure due to bankruptcy is likely to impede restart owing to the financial affliction by remaining debts and financing problems resulting from the failure. However, if the legal form of the former business stands for capital protection due to limited liability the type of failure does not matter that much. The findings of Metzger (2008) give an idea about how financial afflictions resulting from abandoning a business affect the restart likelihood since the occurrence of start-up financing problems depends on the type of business closure (Metzger, 2007a). He shows that particularly previous bankruptcy increases the likelihood to be faced with start-up financing problems. Consequently, both the existence of and the access to financial means seem to be restricted in case of previous business failure.

However, since the data applied in Metzger (2008) does not allow a disentanglement between willingness and feasibility he cannot differ between effects resulting from negative expectancies and capital restrictions. Information about the occurrence of real financial losses resulting from business closure can help to separate these effects. Financial losses arising from business closure can impact various stakeholders: shareholders, banks and public institutions, or suppliers and other stakeholders. It is reasonable to expect that financial losses impact the likelihood of a restart as a function of the stakeholders who have been forced to bear losses. Four out of five start-ups capitalize on entrepreneurs' own capital, one out of five start-ups applies banks loans and further 20 percent utilizes money from family and friends (Metzger, 2007a). There is thus a high probability that entrepreneurs themselves are financially affected by losses incurred from business closure, which, as a consequence, reduces personal wealth, the fundament of future actions. 
However, it is of twofold importance if banks suffer losses. First, losses at banks are likely to be strong correlated with personal losses of the entrepreneurs reducing entrepreneurs' personal wealth. Second, losses at banks are "public" debts impeding the chance of credit from other banks. Credit defaults are recorded by credit bureaus. This worsens an entrepreneurs' credit rating and, as a consequence, reduces the chance for a credit approval. Even if the latter point might be less problematic in Germany, where individuals and firms traditionally do not hop between banks, but rather cultivate a strong relationship with one principal bank, a so-called Hausbank (house bank), losses at banks can diminish entrepreneurs' personal wealth and block banks as a source of financing, both are bad for restart feasibility.

On the basis of the discussed theoretical arguments and existing empirical evidence following hypotheses can be derived:

$\mathrm{H} 1$ : Business closures which can be considered as failure lowers entrepreneurs' expectancy about future net profits of self-employment and reduces restart likelihood.

$\mathrm{H} 2$ : Financial losses resulting from business closure incurred by shareholders constrain entrepreneurs' financial leeway and reduce restart likelihood more than losses at other stakeholders.

H3: Financial losses resulting from business closure incurred by banks constrain entrepreneurs' financial leeway and reduce restart likelihood.

\section{Data}

In order to conduct the analysis the ZEW Entrepreneurship Study is applied. The data is based on 12,000 observations that have been included in a telephone survey that was carried out between March 1999 and March 2000 among German entrepreneurs who established firms in the years 1990 until 1993. All of these firms operated in the manufacturing, construction, trade or selected service sectors and didn't have the legal forms of freelance, registered society or registered cooperative. Firms from the ZEW Foundation Panel form the parent population for this survey. This panel is based on data provided by Creditreform in semi-annual waves. Creditreform is the largest German credit rating bureau with a comprehensive database of German firms at its disposal.

The survey collected information to the establishment of the interviewed entrepreneurs' firms (e.g. legal status, founding year, and industry affiliation), a possible market exit (e.g. exit year, reasons, and financial losses), a possible restart of any of the entrepreneurs involved in the closed firm (occurrence), and many other firm and entrepreneur characteristics. The observed firms are all independent establishments, i.e. are no branches of other firms. A detailed discussion of the survey is found in Almus et al. (2001).

Concerning the approach used to obtain firm information, several attempts have been made to contact an appropriate interview partner. A firm representative was tried to be called on the basis of the last known firm contact details but (maximum two) firm participants including owners and managers were also tried to be called at their home ad- 
dresses, if the attempt to contact the firm was unsuccessful. Applying this approach, also already closed firms could have been surveyed, which is a distinctive feature of this study.

With 3,702 complete interviews out of the 12,000 sample observations, the response rate was about 31 percent, which is high compared to other German studies conducted by telephone. 1,008 cases of all observation refer to businesses that were already closed at the time of the survey.

In 237 cases out of the about one thousand observations the interviewees stated that a former entrepreneur of the closed firm restarted, i.e. established a new business in the meanwhile. Running the analyses with this information, however, would approve two limitations. Firstly, a number of interviewees said that they actually do not know about the venture activities of the closed firms' former entrepreneurs. Secondly, a long time passed since the survey was conducted resulting in outdated information about the venture activities gathered in the study. Either of both issues advises to look for additional information about the venture activities of the relevant individuals. To do so, the entrepreneurs who participated in a closed venture were traced in the data deliveries of Creditreform following subsequently to the state of the ZEW Foundation Panel which forms the parent population of the survey. With this approach it was possible to identify 225 additional restarts up top the year 2007 which wouldn't have been considered referring solely to the survey data.

\section{Selection of variables}

The hypotheses are tested within a multivariate framework. The occurrence of an entrepreneurial restart is the dependent variable in a probit estimation. The dependent variable RESTART equals one if an entrepreneur of a closed business' entrepreneurial team ventures anew and zero otherwise. Two different specifications are fitted. In the first specification the second set of main covariates, i.e. the variables indicating which group of stakeholders incurs financial losses, is omitted and then introduced in the second specification. This enables to identify possible effect which may arise from an omitted variable bias if neglecting these variables.

As shown in Table 1 the introduced independent variables can be subdivided into main covariates and other control variables. Two primary sets of explanatory variables are introduced to account for different closure reasons and for the stakeholder groups which have suffered financial losses from closure. Other ancillary independent variables control for specific firm characteristics; these include governance, legal status, size, location and industry affiliation 
Table 1: Definition of variables

\begin{tabular}{|c|c|c|c|}
\hline Variable & Definition & $\begin{array}{l}\text { Hypothesis } \\
\text { tested }\end{array}$ & $\begin{array}{c}\text { Expected } \\
\text { sign of } \\
\text { effect }\end{array}$ \\
\hline \multicolumn{4}{|c|}{ Main covariates I: Closure reasons ${ }^{a}$} \\
\hline DEBTS & $=1$ if closure due to excessive debts & $\mathrm{H} 1$ & - \\
\hline NOTWORTH & $\begin{array}{l}=1 \text { if closure because business didn't meet entrepreneur's target } \\
\text { performance threshold }\end{array}$ & & ? \\
\hline ILLIQUIDITY & $=1$ if closure due to liquidity problems & $\mathrm{H} 1$ & - \\
\hline WAGEEMPL & $=1$ if closure because entrepreneur transitioned to workforce & & - \\
\hline RETIRE & $=1$ if closure because entrepreneur went into retirement & & - \\
\hline PRIVATE & $=1$ if closure because of private reasons & & $?$ \\
\hline OTHERREAS & $=1$ if closure because of other reasons & & $?$ \\
\hline QUARREL & $\begin{array}{l}=1 \text { if closure due to differences within the entrepreneur team } \\
\text { (the effect of this variable has to be interpreted jointly with } \\
\text { the TEAM indicator) }\end{array}$ & & $?$ \\
\hline \multicolumn{4}{|c|}{ Main covariates II: Bearer of financial losses ${ }^{a}$} \\
\hline SHAREHOL & $\begin{array}{l}=1 \text { if entrepreneurs incurred financial losses due to the business } \\
\text { closure }\end{array}$ & $\mathrm{H} 2$ & - \\
\hline BANKS & $\begin{array}{l}=1 \text { if banks or public institutions incurred financial losses due to } \\
\text { the business closure }\end{array}$ & H3 & - \\
\hline OTHERSTAKE & $\begin{array}{l}=1 \text { if other stakeholders (like suppliers) incurred financial losses } \\
\text { due to the business closure }\end{array}$ & & $?$ \\
\hline \multicolumn{4}{|c|}{ Control variables } \\
\hline CAPITAL & $=$ Amount of start-up capital utilized in the closed firm (in '000 €) & & $?$ \\
\hline CAPITALM & $=1$ if the amount of capital is not available & & \\
\hline TEAM & $=1$ if firm was ruled by an entrepreneur team & & + \\
\hline TEAMM & $=1$ if the TEAM indicator is missing & & \\
\hline LIMITED & $=1$ if the firm's legal status was liability limiting & & 0 \\
\hline SIZE & $=\#$ of employees at firm closure & & + \\
\hline SIZEM & $=1$ if firm size is not available & & \\
\hline AGE & $=$ Age of the closed firm (in years) & & $?$ \\
\hline AGEM & $=1$ if firm age is not available & & \\
\hline EAST & $=1$ if the firm was located in East Germany & & 0 \\
\hline HTIND & $=1$ if the firms was affiliated in a high-tech industry sector & & 0 \\
\hline OTHERIND & $=1$ if the firms was affiliated in a non-high-tech industry sector & & + \\
\hline TECHSERV & $=1$ if the firms was affiliated in a high-tech service sector & & + \\
\hline OTHERSERV & $=1$ if the firms was affiliated in a non-high-tech service sector & & + \\
\hline CONSTRUCT & $=1$ if the firms was affiliated in construction & & + \\
\hline TRADE & $=1$ if the firms was affiliated in trade services & & + \\
\hline
\end{tabular}

a Multiple statements were possible.

Note: The expected signs of the control variables' effects are suggested by the findings of Metzger (2008).

There are different closure reasons that could be developed from the interviewees answers, which led to eight indicators. The indicator DEBTS refers to closures due to excessive debts. It is a closure reason that suggests business failure and which is thus an appropriate indicator to test hypothesis $\mathrm{H} 1$ owing to which negative effects are expected. NOTWORTH is a further closure reason variable. It refers to closures that occur because they do not meet the entrepreneurs' target threshold of performance. However, no expectation about the effect of this measure is derived. At the one hand, entrepreneurs who close a business because they recognize that a going concern is not worth it, might regard themselves as being failed preventing them from restart. At the other hand, they may hold the opinion that this experience improved their entrepreneurial talent confirm- 
ing them to restart. Another indicator is ILLIQUIDITY. It refers to closures due to liquidity problems. Concerning ILLIQUIDITY the similar applies as with regard to the before discussed measure NOTWORTH: there is no clear expectation about how it affects restart likelihood. ILLIQUIDITY may be an equivalent indicator for failure as DEBTS is, however, illiquidity can also be a problem of firms which are basically economically sound. One single big customer with default in payment is sufficient to plunge a firm into liquidity distress.

The variables WAGEEMPL and RETIRE refer to closures which occur because entrepreneurs either changed into wage employment or went into retirement. Due to such a shift of the income source negative effects on the restart likelihood are expected. Finally, the variable PRIVATE refers to business closures because of private reasons, OTHERREAS refers to other not further specified reasons, and QUARREL refers to quarrels within the entrepreneur team. Since the latter closure reason is only possible if there is an entrepreneur team, effects referring to it have to be interpreted jointly with the indicator accounting for team governance. For all three variables PRIVATE, OTHERREAS, and QUARREL no expectations about the effects are derived.

\section{Results}

Table 2 shows the mean values of the introduced independent variables. Almost a quarter of the surveyed closures can be considered as business failures since in 24 percent of the closures excessive debts play a major role. The target thresholds of performance were missed in 38 percent of the closures. Liquidity problems contribute in 45 percent of the cases to the closure decision. About 6 percent of the closures exited because entrepreneurs changed into wage employment, while a change into retirement are relevant for 4 percent of the closures. Private or other reasons were important in 13 and 21 percent of the closure cases. Finally, quarrel within the entrepreneur team plays a role in about 14 percent of the closures.

"Entrepreneurs risk their financial well-being, career opportunities, family relations, and physical well-being" (Liles, 1974). This recognition is fairly true as the 61 percent share of entrepreneurs who incurred financial losses due to their business closure suggests. At a first glance, this finding does not agree with Dennis and Fernald (2001) who note that "the chances of financial success in terms of change in personal financial condition are substantially greater than the chances of loss". Stating so they refer to their findings based on exits implying both exits due to real closures and due to sale of shareholdings. Indeed, a exit of the latter type is associated with a freeing of capital (Stam et al., 2006) and probably with capital gains. However, referring solely on business closures the data of Dennis and Fernald (2001) also show that slightly more than half of all entrepreneurs suffer losses due to business closure which is comparable with the finding herein. Banks and public institutions suffered losses in 22 percent of the closures, while in 31 percent of the closures other stakeholder like suppliers must incur losses. 
Table 2: Variable means

\begin{tabular}{|c|c|c|c|c|c|}
\hline Variable & Mean & Unit & Variable & Mean & Unit \\
\hline Main covariates I: Closure reasons ${ }^{\text {a }}$ & & & Control variables & & \\
\hline DEBTS & 23.7 & $\%$ & CAPITAL & 64.7 & $1000 €$ \\
\hline NOTWORTH & 37.9 & $\%$ & CAPITALM & 33.9 & $\%$ \\
\hline ILLIQUIDITY & 45.3 & $\%$ & TEAM & 55.5 & $\%$ \\
\hline WAGEEMPL & 5.5 & $\%$ & TEAMM & 7.3 & $\%$ \\
\hline RETIRE & 4.1 & $\%$ & LIMITED & 48.9 & $\%$ \\
\hline PRIVATE & 12.8 & $\%$ & SIZE & 11.8 & \# Employees \\
\hline OTHERREAS & 21.2 & $\%$ & SIZEM & 8.4 & $\%$ \\
\hline \multirow[t]{2}{*}{ QUARREL } & 13.7 & $\%$ & AGE & 4.1 & Years \\
\hline & & & AGEM & 3.6 & $\%$ \\
\hline Main covariates II: Bearer of financial losses ${ }^{a}$ & & & EAST & 51.6 & $\%$ \\
\hline SHAREHOL & 61.0 & $\%$ & HTIND & 2.0 & $\%$ \\
\hline BANKS & 21.6 & $\%$ & OTHERIND & 11.4 & $\%$ \\
\hline \multirow[t]{4}{*}{ OTHERSTAKE } & 30.7 & $\%$ & TECHSERV & 4.8 & $\%$ \\
\hline & & & OTHERSERV & 6.8 & $\%$ \\
\hline & & & CONSTRUCT & 20.5 & $\%$ \\
\hline & & & TRADE & 37.1 & $\%$ \\
\hline
\end{tabular}

a Multiple statements were possible.

Source: ZEW Entrepreneurship Study.

The measures WAGEEMPL and RETIRE indicate a shift in the source of income. However, as WAGEEMPL is insignificant, a return to the workforce does not affect the likelihood of restart. RETIRE, by contrast, is significantly negative, meaning that in most cases entering retirement is a final decision. A significantly negative effect on the likelihood of restart is also associated with the variable PRIVATE. Business closure due to private reasons such as illness makes restart more unlikely, while OTHERREAS, i.e., unspecified other reasons, is insignificant, thus having no impact. If an argument within the entrepreneurial team was a reason for business closure, this seems - for logical reasons - to encourage entrepreneurs to venture anew; the effect of QUARREL is significantly positive.

Table 3 provides the probit estimation results. Effects arising from the closure-reason indicators are shown in the upper part of the table followed by the effects arising from the loss measures in the lower part. The second and third row presents results for the first specification which omits the loss indicators. The effect of the measure DEBTS is significantly positive in this first specification. There is thus evidence that closures indicative of business failure reduce the likelihood of restart, confirming the findings of Metzger, 2008). NOTWORTH is not significant either, meaning that if entrepreneurs close a business because it fails to meet their target performance threshold, their restart probability is not affected by this experience. Liquidity problems are the most important closure reason, but do not affect the restart decision, as suggested by the insignificance of the ILLIQUIDITY indicator.

The measures WAGEEMPL and RETIRE indicate a shift in the source of income. However, as WAGEEMPL is insignificant, a return to the workforce does not affect the likelihood of restart. RETIRE, by contrast, is significantly negative, meaning that in most cases entering retirement is a final decision. A significantly negative effect on the likelihood of restart is also associated with the variable PRIVATE. Business closure due to private rea- 
sons such as illness makes restart more unlikely, while OTHERREAS, i.e., unspecified other reasons, is insignificant, thus having no impact. If an argument within the entrepreneurial team was a reason for business closure, this seems - for logical reasons - to encourage entrepreneurs to venture anew; the effect of QUARREL is significantly positive.

Table 3: Probit estimation results

\begin{tabular}{|c|c|c|c|c|}
\hline \multirow{2}{*}{$\begin{array}{l}\text { Independent variable: } \\
\text { Occurrence of restart (yes/no) }\end{array}$} & \multicolumn{2}{|c|}{ Specification I } & \multicolumn{2}{|c|}{ Specification II } \\
\hline & Marginal effect ${ }^{a}$ & P-value & Marginal effect ${ }^{a}$ & P-value \\
\hline \multicolumn{5}{|c|}{ Main covariates I: Closure reasons ${ }^{b c}$} \\
\hline DEBTS & $-0,082 * *$ & 0,041 & $-0,061$ & 0,143 \\
\hline NOTWORTH & 0,007 & 0,859 & $-0,001$ & 0,988 \\
\hline ILLIQUIDITY & 0,012 & 0,723 & 0,027 & 0,463 \\
\hline WAGEEMPL & 0,036 & 0,634 & 0,036 & 0,639 \\
\hline RETIRE & $-0,247 * * *$ & 0,000 & $-0,254 * * *$ & 0,000 \\
\hline PRIVATE & $-0,106 * *$ & 0,044 & $-0,107 * *$ & 0,040 \\
\hline OTHERREAS & 0,038 & 0,374 & 0,038 & 0,372 \\
\hline QUARREL & $0,193 * * *$ & 0,000 & $0,192 * * *$ & 0,000 \\
\hline \multicolumn{5}{|c|}{ Main covariates II: Bearer of financial losses ${ }^{b}$} \\
\hline SHAREHOL & - & - & $-0,017$ & 0,645 \\
\hline BANKS & - & - & $-0,112 * *$ & 0,013 \\
\hline OTHERSTAKE & - & - & 0,024 & 0,573 \\
\hline \multicolumn{5}{|l|}{ Control variables } \\
\hline CAPITAL & 0,000 & 0,482 & 0,000 & 0,412 \\
\hline CAPITALM & $-0,010$ & 0,771 & $-0,008$ & 0,830 \\
\hline TEAM & $0,134 * * *$ & 0,000 & $0,135 * * *$ & 0,000 \\
\hline TEAMM & 0,005 & 0,946 & $-0,005$ & 0,941 \\
\hline LIMITED & $0,161 * * *$ & 0,000 & $0,158 * * *$ & 0,000 \\
\hline SIZE & $0,003 * * *$ & 0,001 & $0,003 * * *$ & 0,001 \\
\hline SIZEM & 0,043 & 0,443 & 0,043 & 0,433 \\
\hline AGE & $-0,023 * * *$ & 0,001 & $-0,022 * * *$ & 0,001 \\
\hline AGEM & $-0,144$ & 0,129 & $-0,154$ & 0,108 \\
\hline EAST & $-0,037$ & 0,237 & $-0,035$ & 0,264 \\
\hline HTIND & $-0,006$ & 0,961 & $-0,008$ & 0,943 \\
\hline OTHERIND & 0,020 & 0,749 & 0,025 & 0,681 \\
\hline TECHSERV & $0,230 * * *$ & 0,001 & $0,232 * * *$ & 0,001 \\
\hline OTHERSERV & $0,131 *$ & 0,054 & $0,132 *$ & 0,051 \\
\hline CONSTRUCT & $0,107 * *$ & 0,034 & $0,111 * *$ & 0,027 \\
\hline TRADE & $0,080 *$ & 0,074 & $0,083 *$ & 0,063 \\
\hline \# of observations & 853 & & 853 & \\
\hline Wald $X^{2}$ (df) & $146.820(20)$ & & $159.330(27)$ & \\
\hline Pseudo $\mathrm{R}^{2}$ & 0.161 & & 0.168 & \\
\hline
\end{tabular}

${ }^{\text {a }}$ Average marginal effect.

${ }^{\mathrm{b}}$ No reference category because multiple statements were possible.

${ }^{c}$ Actually, there is another closure reason indicator available namely "change into a different self-employment business". Since this indicator would completely determine the outcome in the regression, 13 observations which exclusively refer to this closure reason are not used.

${ }^{*}$ Significant at the $10 \%$ level. ${ }^{* *}$ Significant at the $5 \%$ level. ${ }^{* * *}$ Significant at the $1 \%$ level.

Note: Both indictors variance inflation factor and condition number do not indicate a multicollinearity problem.

Source: Own regression based on the ZEW Entrepreneurship Study and the ZEW Foundation Panel. 
The fourth and fifth rows provide the results for the second, fully specified estimation. The financial loss indicators capture effects which were associated in the first specification with closure reasons. Contrary to the results of the first specification, the findings of the second specification show that DEBTS now does not significantly affect the likelihood of restart. Closures indicative of failure thus have no influence on whether or not entrepreneurs restart - a surprising finding, indicating that entrepreneurs are neither discouraged when their business fails, nor do they come to the conclusion they are unfit for selfemployment. However, this is in line with findings of Stokes and Blackburn (2002), who report that entrepreneurs believe they can certainly succeed with another business even after having failed. Such a view may not be rational, but is the result of psychological defence mechanisms by which individuals blame external circumstances - such as an unfavourable economic climate - for their failure rather than their own incapacities (see Van den Steen, 2004 for a compilation of relevant citations).

The financial loss indicators also reveal some interesting effects. Surprisingly, the variable SHAREHOL was not significant. This contradicts expectations: if shareholders, i.e., the entrepreneurs, suffer financial losses due to business closure, this plays no role in the likelihood of restart. This finding could mean that entrepreneurs are often able to rescue a large portion of their private capital after being forced to close their business. However, it could also mean that entrepreneurs who restart are simply able to acquire the capital they need, regardless of the depletion of their private resources.

By contrast, results for the BANKS variable conform with expectations. The effect is negatively significant meaning that financial losses due to business closure considerably lower the likelihood of restart.

\section{I mplications}

The results of this study have some important implications for both policymakers and entrepreneurs. Actually, the political position concerning failed entrepreneurs is that one should "promote the fresh start of previously failed businesses, by enabling and empowering them to begin new activities without being hindered by restrictions [because they] do learn from their mistakes and are more successful in the future" (European Commission, 2002, p. 9). In the recent years several multivariate empirical studies refute this outperformance myth (Kay et al., 2004, Metzger, 2006, Metzger, 2007b, Ucbasaran et al., 2006), which was started or at least revived by a study of BCG (Boston Consulting Group, 2002). In consequence these studies query the claim for special support. The findings herein show, however, that solely the fact of business failure does not deter entrepreneurs from restart. Even if the failure results in private financial losses entrepreneurs' restart likelihood remains unaffected. This is different to the occurrence of financial losses at banks or public institutions. Such kind of losses reduces restart likelihood. Many of persons might argue now, that this is the proof for the need of special support particularly since one knows that previously failed entrepreneurs are more likely to have financing difficulties (Metzger, 2007a). However, it must be clear that any person having debts at banks typically will have problems to get money independent if she is a previously failed entrepreneur or not. For example, novice entrepreneurs who are burdened with old debts are likely to have financing difficulties, too. Doubts in the claim for particu- 
lar public support are also endorsed by the fact, that if previously failed entrepreneurs actually restart, their start-up financing composition and the financing sources tapped are not significantly different from that of other entrepreneurs (Metzger, 2007a) suggesting that entrepreneurs who want to restart select themselves into adequate financing.

However, the major finding of this analysis is that financial losses due to business closure strongly influence the likelihood of entrepreneurial restart - yet only when losses are incurred by banks. This has an important implication for entrepreneurs. Entrepreneurs who would seek to continue their entrepreneurial career after a business closure would be well advised to avoid causing losses at banks or at public financial institutions. This advice is worth heeding if a business does not meet entrepreneur's target performance threshold. Then, entrepreneurs either can keep the ailing business afloat or can foresightedly close the business. Frequently, entrepreneurs forfeit the opportunity for a wellmanaged closure in such a situation because they overly optimistic trust in better times. However, in doing so, they risk a worsening of the business' economic situation that consequently would deteriorate their restart chances. ${ }^{1}$

\section{References}

Almus, M., S. Prantl, J. Brüderl, K. Stahl and M. Woywode. 2001. Die ZEW-Gründerstudie - Konzeption und Erhebung. ZEW Dokumentation No. 01-01. Mannheim.

Boston Consulting Group. 2002. Setting the Phoenix Free - A Report on Entrepreneurial Restarters, The Boston Consulting Group, Munich.

Dennis, W.J. and L.W. Fernald. 2001. The Chances of Financial Success (and Loss) from Small Business Ownership. Entrepreneurship Theory and Practice 26(1): 75-83.

Dyer, W.G. 1994. Toward a Theory of Entrepreneurial Careers. Entrepreneurship Theory \& Practice: 7-21.

European Commission. 2002. Best Project on Restructuring, Bankruptcy and a Fresh Start. Enterprise Directorate-General. Brussels.

Jovanovic, B. 1982. Selection and the Evolution of Industry. Econometrica 50(3): 649670.

Kay, R., P. Kranzusch, O. Suprinovic and A. Werner. 2004. Schriften zur Mittelstandsforschung - Restart - Eine zweite Chance für gescheiterte Unternehmer?, Institut für Mittelstandsforschung Bonn, Bonn.

Liles, P.R. 1974. New business ventures and the entrepreneur. Homewood: Irwin.

McGrath, R.G. 1999. Falling Forward: Real Options Reasoning and Entrepreneurial Failure. Academy of Management Review 24(1): 13-30.

Metzger, G. 2006. Once Bitte, Twice Shy? The Performance of Entrepreneurial Restarts. ZEW Discussion Paper No. 06-083. Mannheim.

Metzger, G. 2007a. On the Role of Entrepreneurial Experience for Start-up Financing ZEW Discussion Paper No. 07-047. Mannheim.

Metzger, G. 2007b. Personal experience: a most vicious and limited circle!? ZEW Discussion Papers No. 07-046. Mannheim.

Metzger, G. 2008. Habitual Entrepreneurs in Germany. Ph.D. Thesis. Chair of Business Dynamics, Innovation, and Economic Change. Friedrich Schiller University. Jena.

\footnotetext{
${ }^{1}$ A trivariate probit regression where the independent variables in the three equations refer to the occurrence of financial losses (1) at the entrepreneurs, (2) at banks and public institutions, and (3) at other stakeholders (not reported, on demand available from the author) reveals that a closure which happened because the business missed the entrepreneurs' target threshold of performance is associated with a significant lower risk of losses at both banks and public institutions as well as other stakeholders.
} 
Ronstadt, R. 1982. Does Entrepreneurial Career Path Really Matter? Proceedings of Babson College Entrepreneurship Research Conference, Wellesley, Mass: Center for Entrepreneurial Studies, Babson College.

Ronstadt, R. 1986. Exit Stage Left: Why Entrepreneurs End their Entrepreneurial Careers before Retirement. Journal of Business Venturing 1: 323-338.

Schutjens, V. and E. Stam. 2006. Starting Anew: Entrepreneurial Intentions and Realizations Subsequent to Business Closure. Discussion Papers on Entrepreneurship, Growth, and Public Policy No. 1006. Jena.

Sheperd, D.A. 2003. Learning from Business Failure: Propositions of Grief Recovery for the Self-Employed. Academy of Management Review 28(2): 318-328.

Stam, E., D.B. Audretsch and J. Meijaard. 2006. Renascent Entrepreneurship. Discussion Papers on Entrepreneurship, Growth, and Public Policy No. 0606. Jena.

Stokes, D. and R. Blackburn. 2001. Opening up Business Closures: a Study of Businesses that Close and Owners' Exit Routes. Kingston University. Kingston Hill.

Stokes, D. and R. Blackburn. 2002. Learning the Hard Way: the Lessons of Ownermanagers who Have Closed their Businesses. Journal of Small Business and Enterprise Development 9(1): 17-27.

Ucbasaran, D., P. Westhead and M. Wright. 2006. Habitual Entrepreneurs. Cheltenham (UK) and Northampton, Massachusetts (US): Edward Elgar Publishing.

Van den Steen, E. 2004. Rational Overoptimism (and Other Biases). The American Economic Review 94(4): 1141-1151.

Wagner, J. 2003. Taking a Second Chance: Entrepreneurial Re-starters in Germany. Applied Economics Quarterly 49(3): 255-272. 